DOI: http://doi.org/10.31617/k.knute.2019-04-12.70

Bonistawska B., Doctor inż., Professor European University of Informatics and Economics in Warsaw,

Warsaw, Poland

\title{
PROBLEMS OF PUBLIC ADMINISTRATION IN POLAND
}

The Act on crisis management with amendments introduced numerous changes in the organization of crisis management. This legal act (together with implementing acts) constitutes a basis for building an effective crisis management system in Poland. This multi-element and multilevel system guarantees co-ordination of crisis management actions undertaken at all levels of public administration (both government and selfgovernment) in the country. During its operation the system undergoes consistent changes and improvements.

Procedures identified in plans differ due to the type of threat, however, they have a lot of common elements. After the information about the threat appears it is necessary to contact the centers for crisis management at the higher level. Some information is obtained from higher-level institutions. Higher-level institutions for a community can be District and Voivodeship Center for Crisis Management. Maintaining contact is also necessary to collect information from services (police and fire brigades) and from institutions (health Inspection, Veterinary Inspection when needed). Such information are further used to analyze data, to evaluate the scope of occurrence and to estimate the risk of its further spreading. It is necessary to control the development of situation and to report ti competent persons about all the changes in dynamic of events - increasing or decreasing threats. The actions also include creating and launching information for people and after the information is accepted by a competent authority. The actions are very often taken by competent bodies before all the circumstances, defined in the Act as crisis situation, appear. Crisis situation appears faster in people's perception, that is why together with actions taken by public administration and rescue actions it is important to begin to communicate with the society.

Every crisis situation is a responsibility of a leading institution a competent body for a specific crisis situation which, due to its substantive scope, character of actions and experience, manages the crisis situation and is in charge of information policy. The information which is launched has to be coherent, it means that all the authorities, that take part in elimination of crisis situation, must launch consistent information. It is a common practice to establish the Press Crisis Team which consists of 
representatives of the bodies involved in crisis elimination but it has to stressed that it is a competent in the specific crisis situation authority decides if and when it is necessary to establish the Press Crisis Team. All undertaken communication actions cannot be limited to communication via media. Communication process must include society (and it concerns people who are in direct danger of a crisis situation, who suffered from crisis and their families), must take place inside the institution, between institutions involved in elimination of crisis situation. The information should be launched regularly and it concerns both media information as well as communication with the society. The communication with the society must be regular and must include information on how to behave, where to look for help and what actions have been taken to eliminate crisis situation.

Alerting the people is carried out as a part of alert system which involves alarm sirens, others means of signal, loudspeakers as well as radio, telecommunication and internet systems. Alarm messages should contain recognition, specific instructions, commands to execute (evacuation). Alarm messages should be addressed first of all to people from the area of direct danger. Alarm messages should be repeated regularly until the alarm is cancelled.

Crisis management derives from management understood as organized actions of public administration bodies (government and selfgovernment). The essence of crisis management shell be the activity aiming at counteracting and effective responding to risk to people's life, health and property and taking over the previously planned control actions in case of threat. Planned crisis management actions involve the actions which aim at rebuilding infrastructure, resources and removing the effects of the crisis.

\section{References}

1. Krzeszowski W., Więcek W. Zarządzanie w sytuacjach kryzysowych, Akademia Obrony Narodowej, Warszawa, 2010.

2. Lidwa W., Krzeszowski W., Więcek W. Zarządzanie w sytuacjach kryzysowych., Akademia Obrony Narodowej, Warszawa, 2010.

3. Sienkiewicz-Małyjurek K., Krynojewski F. R. Zarządzanie kryzysowe w administracji publicznej, Difin, Warszawa, 2010.

4. Skomra W. Zarządzanie kryzysowe - praktyczny przewodnik po nowelizacji ustawy, Presscom, Wrocław, 2010.

5. The National Crisis Management Plan from the year 2012 http://www.rcb.gov.pl/wp-content/uploads/2012/03/KPZK.pdf [access 01.03.2019]. 